\title{
Designation of a lectotype for the Canestrini's Goby, Gobius canestrinii Ninni, 1883 (Teleostei, Gobiiformes, Gobiidae, Gobionellinae)
}

\author{
Harald AHNELT ${ }^{1,2^{*}}$, Christelle TOUGARD ${ }^{3}$ and Marcelo KOVAČIĆ ${ }^{4}$ \\ ${ }^{1}$ Department of Evolutionary Biology, Faculty of Life Sciences, University of Vienna, \\ Althanstraße 14, 1090 Vienna, Austria \\ ${ }^{2}$ First Zoological Department, Natural History Museum of Vienna, Burgring 7, \\ 1010 Vienna, Austria \\ ${ }^{3}$ ISEM, Université de Montpellier, CNRS, EPHE, IRD, Montpellier, France \\ ${ }^{4}$ Natural History Museum Rijeka, Lorenzov prolaz 1, HR-51000 Rijeka, Croatia \\ *Corresponding author: harald.ahnelt@univie.ac.at
}

A recent study based on molecular biological data revealed that Gobius canestrinii (Ninni, 1883), a gobioid fish endemic to the Adriatic basin, has to be split in three lineages. The original description was based on populations from two distant localities in Italy and in Croatia respectively, the first representing one of these lineages, the second most likely belonging to another lineage. To fix the name of the species, we hereby designated a lectotype for Canestrini's Goby.

Key words: Gobiidae; Gobius canestrinii; taxonomy; lectotype; Venice, Italy

ZooBank Article LSID: urn:1sid:zoobank.org:pub:2E8EA3A1-6ED5-4CE6-9FE5-E7AB14201451

\section{INTRODUCTION}

A recent study based on molecular data and species delimitation test revealed three lineages of Gobius canestrinii Ninni, 1883, two of them cryptic species (TOUGARD et al., 2021). Nevertheless, as only three populations along the range of $G$. canestrinii were investigated, it is possible that further distinct lineages will be detected. Additionally, Canestrini's Goby seemingly represents a non-monophyletic assemblage of freshwater gobies with at least one of the lineages closely related to Pomatoschistus montenegrensis Miller and Šanda, 2008 (TOUGARD et al., 2021).

The description of Canestrini's Goby was based on samples from two distant localities, one in Italy, Venice lagoon and one in Croatia, river Jadro near Split (NINNI, 1883). The material from Italy was collected by A.P. Ninni, while the Croatian material was sent to him by J. Kolombatović. NINNI (1883) did not mention an exact number of specimens on which the original description of $G$. canestrinii was based. There is also no indication that one of the specimens would have to be addressed as a holotype. Therefore, all specimens have to be considered as syntypes.

To date twelve syntypes are documented: five at the Natural History Museum in Vienna (NMW) and seven at the Zoological Museum "La Specola" of the University of Florence (MZUF) (FRICKE et al., 2021). The five syntypes housed at the NMW (register numbers NMW 


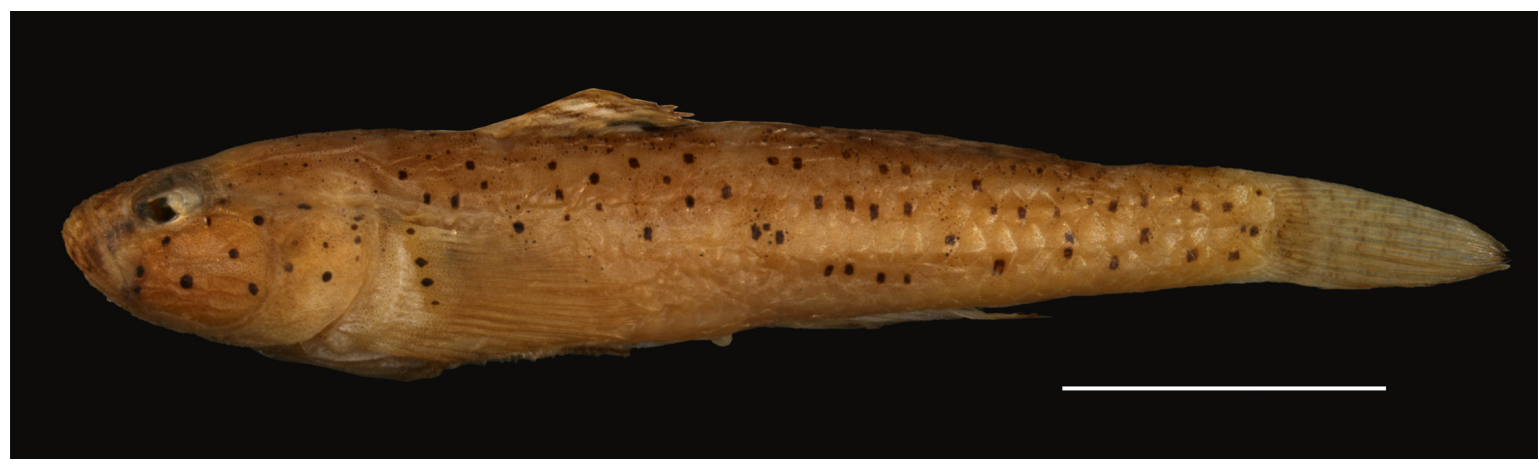

Fig. 1. Lectotype of Gobius canestrinii (NMW 29943). Lateral view. Scale bar: $10 \mathrm{~mm}$. Photograph B. Riedel

28817-28818 and NMW 29943-29945) arrived there before May 1882. Ninni sent these specimens to F. Steindachner, head of the Ichthyological Collection of the K. K. Naturhistorisches Hofmuseum in Vienna, who mentioned in a letter from May 6, 1882 that the new species would be a variety of Gobius quagga Heckel, 1839 (NINNI, 1883). The seven syntypes deposited at MZUF (register numbers MZUF 5577-5583) are dated "22.IV.1883" (VANNI, 1990). All 12 specimens were collected at Venice lagoon (NINNI, 1883). The whereabouts of the type series from the Jadro River (Croatia) is unknown.

The study of TOUGARD et al. (2021) revealed that the population of the Canestrini's Goby from Italy and the two populations from Croatia represent three distinct species. To avoid taxonomical problems, a lectotype for $G$. canestrinii was designated.

\section{RESULTS}

\section{Description of the lectotype}

According to the International Code of Zoological Nomenclature (Art. 74.1, 74.7 and amendment of Art. 74.7.3), a lectotype is herein designated to become the unique bearer of the name $G$. canestrinii. To fix the name of the species, we hereby designate a lectotype for Canestrini's Goby. The specimen is properly labeled at the Ichthyological Collection of the NMW and can be identified by its morphological characters described below. As the Venetian specimens of MZUF are all juvenile, an adult male registered under number NMW 29943, was selected as lectotype (Fig. 1). It is characterized by:
- standard length + caudal fin length (SL + CL) of the lectotype $37.4+7.2 \mathrm{~mm}$; head length $9.7 \% \mathrm{SL}$; snout to origin of first dorsal fin $34.5 \%$ SL; snout to origin of second dorsal fin $55.1 \% \mathrm{SL}$; snout to origin of anal fin $57.5 \%$ SL; body depth at origin of pelvic fin $18.4 \%$ SL; body depth at origin of anal fin $16.3 \%$ SL; caudal peduncle length $26.7 \%$ SL; caudal peduncle depth $1.0 \% \mathrm{SL}$; eye diameter (horizontal) $6.8 \%$ SL; snout length $7.0 \%$ SL; postorbital length $12.7 \% \mathrm{SL}$;

- first dorsal fin with six spiny rays (D1 VI); second dorsal fin with one spiny and nine soft rays (D2 I/9); anal fin with one spiny and eight soft rays (A I/8); pectoral fin with 16 soft rays (P 16); ventral disc, formed by the fused pelvic fins, with one spiny and five soft rays on both sides, the fifth rays of both sides fused with each other along the entire length $(\mathrm{V} \mathrm{I} / 5+5 / \mathrm{I})$. The ventral disc is complete with a distinct membrane expending between both spiny rays; the edge of this membrane is smooth;

- all scales are ctenoid, increasing in size posteriorly; scales are largest on the caudal peduncle; ctenii are small and numerous (2130); 34 scales in lateral midline; trunk anterior to a line of the axilla rearwards to the fourth fin ray of the second dorsal fin (D2 4) naked; head, nape, pre-dorsal area and breast naked;

- head lateral line canal system with anterior oculo-scapular canal (AOS) present; following AOS, pores are developed: B, C (unpaired), D (unpaired), $\mathrm{F}$ and $\mathrm{H}$; pore $\mathrm{E}$ is missing on both sides; posterior oculo-scapular canals (POS) reduced but furrows in the canal bearing bone (post-temporal) still distinct; pre-opercular canal 
(POC) present on the left side with pores $\mathrm{M}$ and $\mathrm{O}$ present; pore $\mathrm{N}$ missing; $\mathrm{POC}$ on the right side missing but furrow in the canal bearing bone (pre-opercle) still distinct;

- free neuromasts and their pattern not discernable because of preservation;

- urogenital papilla elongates and pointed, wide at the base and tapering to the end;

- coloration (preserved): body pale fawn; dorsal side of head and trunk brownish-greyish; indistinct pale blotch dorsal of each opercle but not confluent in the midline; sides of head (cheeks and opercles) and the trunk covered by numerous blackish spots; spots on nape and pre-dorsal area distinctly smaller except for two spots immediately anterior to the origin of the first dorsal fin; four such blackish spots extend as an oblique row on the anterior most part of the pectoral fin; pale mark on base on the origin of the pectoral fin rays anterior to these spots; first dorsal fin with a large, distinct blackish spot which is surrounded by transparent fin membrane; blotch extends from fifth spiny ray on to the post-dorsal membrane.

With the designation of the specimen NMW 29943 as lectotype of $G$. canestrinii the four syntypes registered NMW 28817-28818 and NMW 29944-29945 become paralectotypes (recommendation of ICZN Art. 47.F).

\section{DISCUSSION}

Formerly placed in the genus Pomatoschistus Gill, 1863 by DE BUEN (1930), G. canestrinii was recently transferred to the genus Ninnigobius Whitley, 1951 (THACKER et al., 2019), whereas TOUGARD et al. (2021) found no clear evidence to assign $G$. canestrinii to this genus. However, G. canestrinii is endemic to the Adriatic drainage area and has a disjunct distribution (MILLER, 2004). Divers morphological variations were described on the Croatian samples of the supposed single species of $G$. canestrinii (KOVAČIĆ, 2005). Based on molecular biological data, TOUGARD et al. (2021) split G. canestrinii in three lineages of which one corresponds to one of the type localities of G. canestrinii, the lagoon of Venice in northern Italy. The other two are lineages from Croatia, each one from a single locality. The river Raša lineage in Istria (west Croatia) is closer to the type locality in the Venice lagoon than to the second type locality, river Jadro near Split. The Baćinska Lakes lineage is south from this second type locality, situated in southeast Croatia (MILLER, 2004; KOVAČIĆ, 2005). In order to fix the name of the species, according to the recommendation of the International Code of Zoological Nomenclature (Art. 74.1, 74.7) (International Commission on Zoological Nomenclature, 1999; 2003), one specimen, among the Venetian syntypes of $G$. canestrinii, was chosen as lectotype. The Jadro population, which should be distinct from the Venice population considering the Raša lineage and the Baćinska Lakes lineage in between, is left as an undescribed species, probably related to the Baćinska lakes lineage.

\section{ACKNOWLEDGEMENTS}

We thank Bettina Riedel (NMW) for her help with the type series of Gobius canestrinii and Nina Bogutskaya (NMW) for nomenclatorial advice.

\section{REFERENCES}

DE BUEN, F. 1930. Sur une collection de Gobiinae provenant du Maroc. Essai de synopsis des espèces de l'Europe. Bull. Soc. Sci. Nat. Maroc, 10: 120-147.

FRICKE, R., W.N. ESCHMEYER \& R. VAN DER LAAN. 2021. Eschmeyer's Catalog of Fishes: Genera, Species, References. http://researcharchive. calacademy.org/research/ichthyology/cata- log/fishcatmain.asp [accessed 2021, February 20].

INTERNATIONAL COMMISSION ON ZOOLOGICAL NOMENCLATURE 1999. International Code of Zoological Nomenclature, 4th Edition. The International Trust for Zoological Nomenclature, London, 306 pp.

INTERNATIONAL COMMISSION ON ZOOLOGI- 
CAL NOMENCLATURE 2003. Declaration 44 - Amendment of Article 74.7.3. Bull. Zool. Nomencl., 60: 263.

KOVAČIĆ, M. 2005. Morphological variability of

Pomatoschistus canestrinii (Gobiidae), with

the reduction of squamation and head canals.

Cybium, 29: 373-379.

MILlER, P.J. 2004. Pomatoschistus canestrinii

(Ninni, 1883). In: P.J. Miller (Editor). Freshwater Fishes of Europe. Gobiidae 2: 284

292. Wiebelsheim: AULA-Verlag.

NINNI, A.P. 1883. Nuova specie di Gobius. Atti

Soc. Venet.-Trent. Sci. Nat. Padova, 8: 276279.

THACKER, C.E., C. GKENAS, A. TRIANTAPHYL-
LIDIS, S. MALAVASI \& I. LEONARDOS 2019. Phylogeny, systematics and biogeography of the European sand gobies (Gobiiformes: Gobionellidae). Zool. J. Linn. Soc., 185: 212-225.

TOUGARD, C., J. VUKIĆ, H. AHNELT, I. BUJ, M. KOVAČIĆ, G.A. MORO, P. TUTMAN \& R. ŠANDA 2021. Quaternary climatic cycles promoted (re)colonization and diversification events in Adriatic sand gobies. J. Zool. Syst. Evol. Res., 59. https://doi.org/10.1111/jzs. 12468

VANNI, S. 1990. Cataloghi del Museo Zoologico "La Specola" dell'Università di Firenze. Viii. Osteichthyes: Tipi. Atti Soc. Tosc. Sci. Nat., Mem., Ser. B, 97: 219-229.

Received: 2 March 2021

Accepted: 27 April 2021

\title{
Određivanje lektotipa Canestrinijevog glavoča, Gobius canestrinii Ninni, 1883 (Teleostei, Gobiiformes, Gobiidae, Gobionellinae)
}

\author{
Harald AHNELT, Christelle TOUGARD i Marcelo KOVAČIĆ \\ Kontakte-pošta: harald.ahnelt@univie.ac.at
}

\begin{abstract}
SAŽETAK
Nedavna istraživanja, zasnovana na molekularno biološkim metodama, otkrila su da se Gobius canestrinii (Ninni, 1883), endemski glavoč jadranskog bazena, dijeli u tri filogenetske grane. Izvorni opis vrste zasnivao se na populacijama dva udaljena lokaliteta u Italiji i Hrvatskoj. Populacija u Italiji predstavlja jednu od tri filogenetske grane, dok druga najvjerojatnije predstavlja jednu od preostale dvije grane. Da bi se fiksiralo ime vrste, u ovom radu određujemo lektotip Canestrinijevog glavoča.
\end{abstract}

Ključne riječi: Gobiidae; Gobius canestrinii; taksonomija; lektotip; Venecija; Italija 